Prepared in cooperation with the Minnesota Pollution Control Agency

\title{
Methods to Estimate Historical Daily Streamflow for Ungaged Stream Locations in Minnesota
}



Scientific Investigations Report 2015-5181

U.S. Department of the Interior

U.S. Geological Survey 
Cover photograph: Redwood River near Redwood Falls, Minnesota.

Photograph by the U.S. Geological Survey. 


\section{Methods to Estimate Historical Daily Streamflow for Ungaged Stream Locations in Minnesota}

David L. Lorenz and Jeffrey R. Ziegeweid

Prepared in cooperation with the Minnesota Pollution Control Agency

Scientific Investigations Report 2015-5181 


\title{
U.S. Department of the Interior SALLY JEWELL, Secretary
}

\section{U.S. Geological Survey Suzette M. Kimball, Director}

\author{
U.S. Geological Survey, Reston, Virginia: 2016
}

For more information on the USGS - the Federal source for science about the Earth, its natural and living resources, natural hazards, and the environment—visit http://www.usgs.gov or call 1-888-ASK-USGS.

For an overview of USGS information products, including maps, imagery, and publications, visit http://www.usgs.gov/pubprod/.

Any use of trade, firm, or product names is for descriptive purposes only and does not imply endorsement by the U.S. Government.

Although this information product, for the most part, is in the public domain, it also may contain copyrighted materials as noted in the text. Permission to reproduce copyrighted items must be secured from the copyright owner.

\footnotetext{
Suggested citation:

Lorenz, D.L., and Ziegeweid, J.R., 2016, Methods to estimate historical daily streamflow for ungaged stream locations in Minnesota: U.S. Geological Survey Scientific Investigations Report 2015-5181, 18 p., http://dx.doi.org/10.3133/ sir20155181.
}

ISSN 2328-0328 (online) 


\section{Contents}

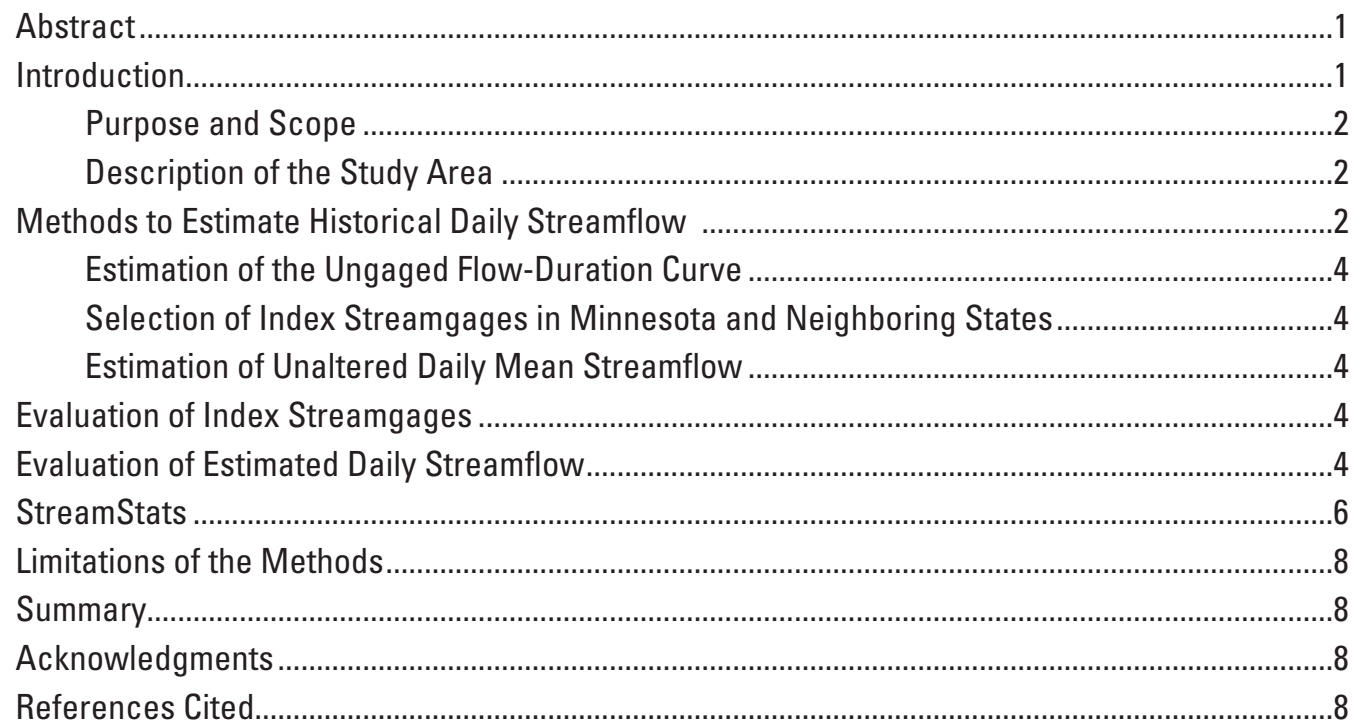

\section{Figures}

1. Map showing Minnesota and parts of neighboring States showing selected index streamgages ............................................................................................................................

2. Graphs showing example of the QPPO method used to estimate daily mean streamflow at ungaged locations for part of the annual hydrograph showing the gaged hydrograph; the gaged flow-duration curve; the estimated flow-duration curve; and the estimated ungaged hydrograph......................................................................

3. Graphs showing observed and estimated streamflows for two target streamgages. streamgage. ( 4 ,

\section{?}

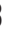
,

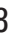




\section{Conversion Factors}

Inch/Pound to International System of Units

\begin{tabular}{lcl}
\hline \multicolumn{1}{c}{ Multiply } & By & To obtain \\
\hline foot $(\mathrm{ft})$ & Length & meter $(\mathrm{m})$ \\
mile $(\mathrm{mi})$ & 0.3048 & kilometer $(\mathrm{km})$ \\
\hline & 1.609 & \\
\hline square mile $\left(\mathrm{mi}^{2}\right)$ & Area & hectare $($ ha $)$ \\
square mile $\left(\mathrm{mi}^{2}\right)$ & 259.0 & square kilometer $\left(\mathrm{km}^{2}\right)$ \\
\hline & 2.590 & \\
\hline cubic foot per second $\left(\mathrm{ft}{ }^{3} / \mathrm{s}\right)$ & Flow rate & cubic meter per second $\left(\mathrm{m}^{3} / \mathrm{s}\right)$ \\
\hline
\end{tabular}

\section{Supplemental Information}

Water year is the 12-month period of October 1 through September 30 and is designated by the calendar year in which it ends.

\section{Datum}

Horizontal coordinate information is referenced to the North American Datum of 1983 (NAD 83).

\section{Abbreviations}

$\begin{array}{ll}\text { BaSE } & \text { Baseline Streamflow Estimator } \\ \text { FDC } & \text { flow-duration curve } \\ \text { GIS } & \text { geographic information system } \\ \text { LFF } & \text { low-flow frequency } \\ \text { MA SYE } & \text { Massachusetts Sustainable-Yield Estimator } \\ \text { MOVE } & \text { maintenance of variance extension } \\ \text { MPCA } & \text { Minnesota Pollution Control Agency } \\ \text { NSE } & \text { Nash-Sutcliffe efficiency } \\ \text { NYSET } & \text { New York Streamflow Estimation Tool } \\ \text { USGS } & \text { U.S. Geological Survey }\end{array}$




\title{
Methods to Estimate Historical Daily Streamflow for Ungaged Stream Locations in Minnesota
}

\author{
By David L. Lorenz and Jeffrey R. Ziegeweid
}

\begin{abstract}
Effective and responsible management of water resources relies on a thorough understanding of the quantity and quality of available water; however, streamgages cannot be installed at every location where streamflow information is needed. Therefore, methods for estimating streamflow at ungaged stream locations need to be developed. This report presents a statewide study to develop methods to estimate the structure of historical daily streamflow at ungaged stream locations in Minnesota. Historical daily mean streamflow at ungaged locations in Minnesota can be estimated by transferring streamflow data at streamgages to the ungaged location using the QPPQ method. The QPPQ method uses flow-duration curves at an index streamgage, relying on the assumption that exceedance probabilities are equivalent between the index streamgage and the ungaged location, and estimates the flow at the ungaged location using the estimated flow-duration curve. Flowduration curves at ungaged locations can be estimated using recently developed regression equations that have been incorporated into StreamStats (http://streamstats.usgs.gov/), which is a U.S. Geological Survey Web-based interactive mapping tool that can be used to obtain streamflow statistics, drainagebasin characteristics, and other information for user-selected locations on streams.
\end{abstract}

\section{Introduction}

Effective and responsible management of water resources relies on a thorough understanding of the quantity and quality of available water. Streamgages provide valuable water-quantity information that facilitates responsible management of water resources, including reservoir management, recreational activities, maintenance of aquatic habitat, and contaminant monitoring; however, streamgages cannot be installed at every location where streamflow information is needed. Therefore, methods for estimating daily mean streamflow at ungaged locations need to be developed. Approaches for estimating daily streamflow have been developed into estimation tools by the U.S. Geological Survey (USGS) in Massachusetts (Massachusetts Sustainable-Yield Estimator [MA SYE]; Archfield and others, 2010), Pennsylvania (Baseline Streamflow Estimator [BaSE]; Stuckey and others, 2012), and New York (New York Streamflow Estimation Tool [NYSET]; Gazoorian, 2015). The MA SYE, BaSE, and NYSET tools apply the QPPQ method introduced by Fennessey (1994) and used by Hughes and Smakhtin (1996), Smakhtin (1999), Smakhtin and Masse (2000), Mahamoud (2008), Shu and Ouarda (2012), and Linhart and others (2013). The QPPQ method uses flowduration curves (FDCs) at an index streamgage, relying on the assumption that exceedance probabilities are equivalent between the index streamgage and the ungaged location, and estimates the flow at the ungaged location using the estimated FDC. The MA SYE and BaSE tools have been effective at estimating the natural, unaltered daily streamflow hydrograph at ungaged locations in their respective study areas and provide user-friendly ways of computing streamflow statistics commonly used for water-resource management and habitat protection. Recently, regression equations were developed to estimate flow-duration exceedance probabilities and low-flow frequency (LFF) statistics for ungaged locations on streams in Minnesota (Ziegeweid and others, 2015). These regression equations can be used to develop methods for estimating daily mean streamflow.

The QPPQ method can be used to assist water-resource managers and researchers to describe and quantify hydrologic variability and describe the hydrologic response of a river basin, and within a wide range of uncertainty, estimate the streamflow at ungaged sites. The measures of variability and streamflow can be used for irrigation planning, wasteload allocation, water-quality management, categorizing fish assemblages and other characteristics of aquatic organisms, and other tasks that require knowledge of the variability of streamflow in small basins.

In 2012, the USGS initiated a statewide study in cooperation with the Minnesota Pollution Control Agency (MPCA) to develop methods for estimating historical daily streamflow at ungaged stream locations in Minnesota. For this study, methods were developed that use FDCs based on regression equations (Ziegeweid and others, 2015) to estimate historical daily streamflow data for ungaged locations on small streams (that is, those with drainage areas less than 3,000 square miles $\left.\left[\mathrm{mi}^{2}\right]\right)$ in Minnesota. 
This study for ungaged stream locations in Minnesota builds upon the work presented in Ziegeweid and others (2015) who developed regression equations for estimating 13 FDC statistics. Those FDC statistics are needed for estimating historical daily streamflow using the QPPQ method at ungaged stream locations in Minnesota.

\section{Purpose and Scope}

This report describes how regression equations developed by Ziegeweid and others (2015) can be used to estimate historical daily streamflow in small streams at ungaged locations in Minnesota. The steps described include (1) constructing FDCs at ungaged locations, (2) selecting index streamgages, and (3) transferring hydrographs from the index streamgage to the ungaged location. Methods presented in this report apply only to streams in Minnesota with drainage areas less than 3,000 $\mathrm{mi}^{2}$ and flows that are not substantially affected by regulation, diversion, or urbanization, which are limitations set by the analysis done by Ziegeweid and others (2015).

The purpose of estimating historical daily streamflow is to describe the hydrograph structure-variability of flow and approximate timing of flows - rather than the actual daily streamflow at the ungaged location. As such, the estimated streamflow is more suitable for management of recreational activities and maintenance of aquatic habitat than for studies of contaminant transport and load estimation, where more accurate streamflow is required. The estimated FDCs could be modified by other mass-balance methods to estimate streamflow that more nearly match the expected daily streamflow for use in water budgets and possibly contaminant transport. Those methods are beyond the scope of this report.

\section{Description of the Study Area}

The study area (fig. 1) includes the State of Minnesota and a 50-mile (mi) buffer around Minnesota in the neighboring States of Iowa, North Dakota, South Dakota, and Wiscon$\sin$. Canadian portions of the basins were not included because basin characteristics were not available in StreamStats (U.S. Geological Survey, 2015). The study area is divided into five hydrologic regions (fig. 1) developed using a combination of statistical analyses from previous studies (Jacques and Lorenz, 1988; Lorenz and others, 1997; Lorenz and others, 2010) and the concept of hydrologic landscape units (Winter, 2001; Wolock and others, 2004). Ziegeweid and others (2015) state "Region BC represents the combined regions B and C from Lorenz and others (2010) because not enough streamgages with low-flow data were available in region $\mathrm{C}$ to develop regional regression equations. Residual analyses confirmed that regions $\mathrm{B}$ and $\mathrm{C}$ could be combined without affecting the ability of the regional regression equations to accurately estimate FDC and LFF statistics."
Differences among the five hydrologic regions are described using the hydrologic landscape unit information presented in Lorenz and others (2010). Region A is the most heterogeneous region, with generally low slopes that become increasingly moderate near the drainage boundary. Most of region $\mathrm{BC}$ is dominated by sandy soils and low to moderate slopes, but the northeastern portion of region $\mathrm{BC}$ along the north shore of Lake Superior and the northeastern Canadian border generally is high in slope. Low slopes near the center of region D change to moderate slopes and less sandy soils around the drainage boundaries. Region $\mathrm{E}$ is similar to the drainage boundaries of region $\mathrm{D}$, with moderate slopes and low sand content in the soils; however, there are distinct differences in the drainage patterns between regions D and $\mathrm{E}$. Finally, high slope areas in region F change to moderately sloped areas along the western drainage boundary.

The study area (fig. 1) includes selected index streamgages in the State of Minnesota, but some selected index streamgages are in the surrounding States of Iowa, North Dakota, South Dakota, and Wisconsin. For the neighboring States, only those streamgages that were used in Ziegeweid and others (2015) are used as index streamgages. For Minnesota, inactive streamgages that have at least 10 years of record and all active (as of 2015) streamgages that are unaffected by regulation, diversion, or urbanization are used as index streamgages. Table 1 ( at the back of this report) provides additional information for the index streamgages shown on figure 1.

\section{Methods to Estimate Historical Daily Streamflow}

Daily mean streamflow can be estimated for ungaged locations in Minnesota by transferring streamflow data at index streamgages to the ungaged location using the QPPQ method (Fennessey, 1994). The QPPQ method uses FDCs at ungaged locations and index streamgages and relies on the assumption that exceedance probabilities are equivalent between an ungaged location and an index streamgage. Details of applying the method are presented in the following sections.

If the ungaged location was previously gaged for a period long enough to establish an FDC (10 years), then the FDC for the location can be based on measured streamflow rather than estimated streamflow. If the gaging period was not long enough to establish an FDC, then the estimated FDC can be used and possibly adjusted by the mean flow to closer approximate streamflow at the ungaged location. In addition, other record-extension methods can be used for previously gaged locations. One common record-extension method is the maintenance of variance extension (MOVE), which adjusts for changes in flow conditions between the concurrent and nonconcurrent records (Hirsch, 1982; Vogel and Stedinger, 1985). 


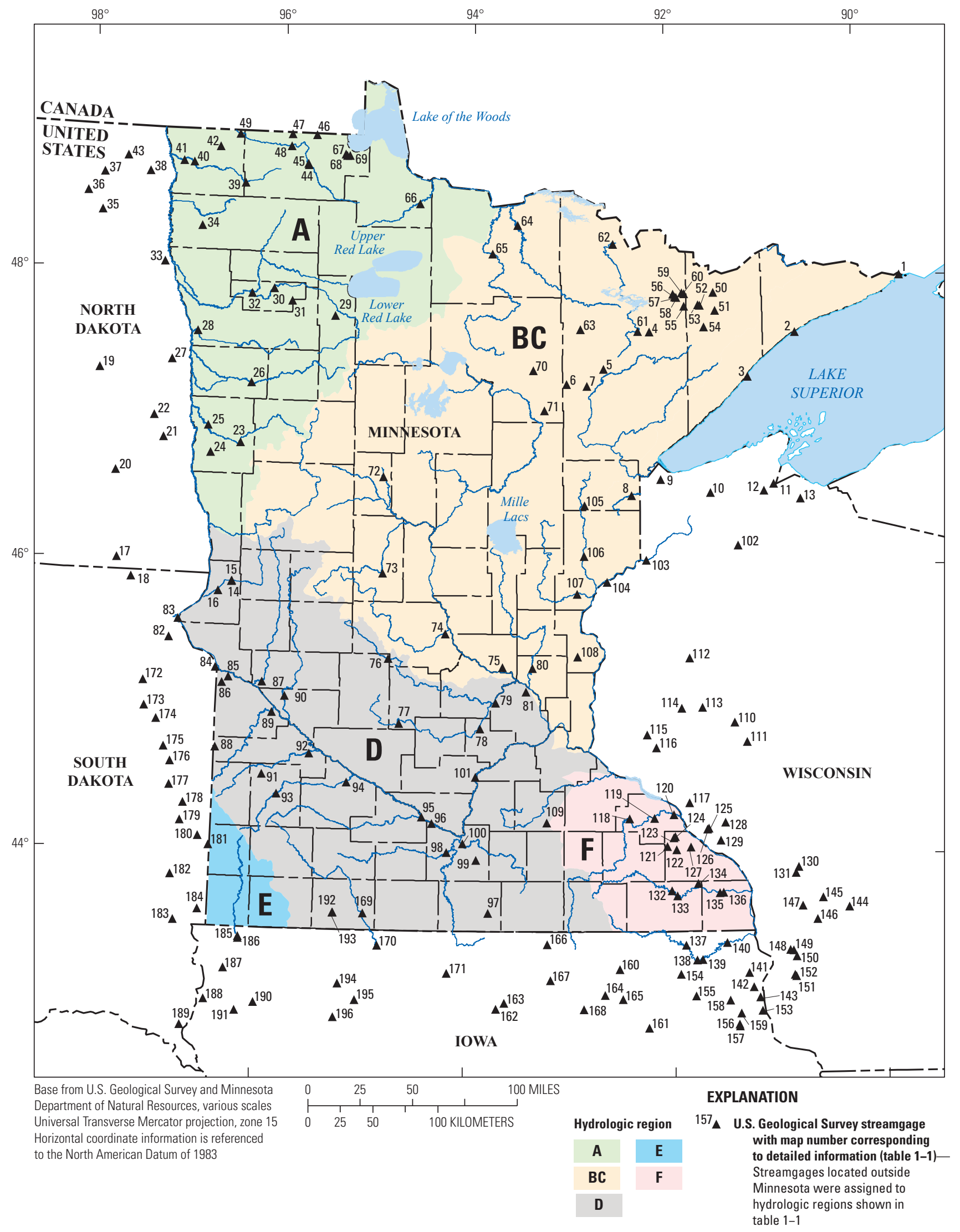

Figure 1. Minnesota and parts of neighboring States showing selected index streamgages. 


\section{Estimation of the Ungaged Flow-Duration Curve}

An FDC is a cumulative frequency curve that shows the fraction of time that specified streamflow is equaled or exceeded (Searcy, 1959). Typically, FDCs are constructed using the complete records for the index streamgage, but FDCs can be constructed from any reference time period. An FDC is built by sorting streamflow observed during a given period of time by magnitude and calculating the probability that a specified streamflow value will be equaled or exceeded. For this report, the fraction of time that the streamflow is equaled or exceeded is termed exceedance probability.

At an ungaged location, the FDC is constructed from point estimates of streamflow for 13 exceedance probabilities (0.0001, 0.001, 0.02, 0.05, 0.1, 0.25, 0.5, 0.75, 0.9, 0.95, 0.99, 0.999 , and 0.9999$)$ that cover the range of streamflow. Regression equations, developed using physical and climatic basin characteristics and streamflow data from a subset of index streamgages, are applied to estimate each of the 13 exceedance probabilities (Ziegeweid and others, 2015). To construct a continuous daily FDC, streamflow at all other exceedance probabilities is determined by log-q-normal interpolation, which interpolates values based on the log of streamflow and the quantile of the normal distribution based on the probability, completing the FDC between the 13 exceedance-probability estimates for the ungaged location.

\section{Selection of Index Streamgages in Minnesota and Neighboring States}

Selection of an index streamgage is an important step in obtaining the best estimates of daily streamflow in an unaltered stream at an ungaged location. Index streamgages can be identified using several methods. Archfield and others (2010) used kriging to maximize the correlation in streamflow between streamgages and potential ungaged locations to identify index streamgages, an approach that works well when examining fixed periods of time. In contrast, Farmer and others (2014) selected index streamgages using the nearestneighbor method. Once index streamgages were selected, both studies (Archfield and others, 2010; Farmer and others, 2014) used the QPPQ method, which is described in the "Estimation of Unaltered Daily Mean Streamflow" section, to estimate daily streamflow at ungaged stream locations. For this Minnesota study, the nearest-neighbor method was used to determine the Spearman rank correlation coefficients (Spearman's rho; Helsel and Hirsch, 2002) between streamgages separated by various distances, and Spearman's rho was used to evaluate whether compared streamgages were suitable index streamgages.

The index streamgage must be unaltered by regulation and similar to the ungaged locations of interest. For the purposes of this report, an index streamgage is defined as the outlet of a basin that has upstream land cover, geology, and hydrologic characteristics similar to the ungaged basin and is based on a similar term in Stuckey and others (2012). A set of index streamgages from the streamgage network in Minnesota and surrounding States was identified to estimate correlations with ungaged locations (table 1). Other streamgages maintained by the USGS, the Minnesota Department of Natural Resources, or other agencies could be used once they have established records of at least 10 years length. It is important that the index streamgage basin characteristics should be relatively similar to the ungaged basin characteristics, particularly the location of lakes or wetlands that affect the timing of streamflow. Possible effects, including peak-flow attenuation and slower response to rainfall, from large lakes and wetlands just upstream from the ungaged or potential index streamgage should be considered when selecting the index streamgage.

\section{Estimation of Unaltered Daily Mean Streamflow}

Daily mean streamflow in unaltered small streams at ungaged locations in Minnesota can be estimated using the QPPQ method (Fennessey, 1994). The three-step process of the QPPQ method is shown in figure 2: (1) for each day, the observed daily mean streamflow at the index station (the "gaged hydrograph") is determined; (2) the probability of exceeding that observed streamflow is determined from the "gaged flow-duration curve" and transferred to the "estimated flow-duration curve"; and (3) the estimated flow for the ungaged location for that day is determined and the "estimated ungaged hydrograph" is constructed.

\section{Evaluation of Index Streamgages}

For streamgages in this study, the nearest-neighbor method produced consistently better Spearman's rho, computed from the estimated and observed streamflows, when drainage-area ratios for the compared streamgages were between 0.25 and 4 than when drainage-area ratios were outside of this range; however, within this range of drainage-area ratios, the Spearman's rho decreased as the distance between streamgages increased. For streamgages about $10 \mathrm{mi}$ apart, Spearman's rho for daily streamflow between streamgages was 0.87 . When the distances between streamgages were increased to about $50 \mathrm{mi}$, Spearman's rho decreased to 0.78 . In the study area, the only potential ungaged locations without a suitable index streamgage within $50 \mathrm{mi}$ are some tributaries to Lake Superior.

\section{Evaluation of Estimated Daily Streamflow}

Observed and estimated streamflows were compared for nine pairs of streamgages (table 2) to assess the performance of the QPPQ method for streams within the study area. The 


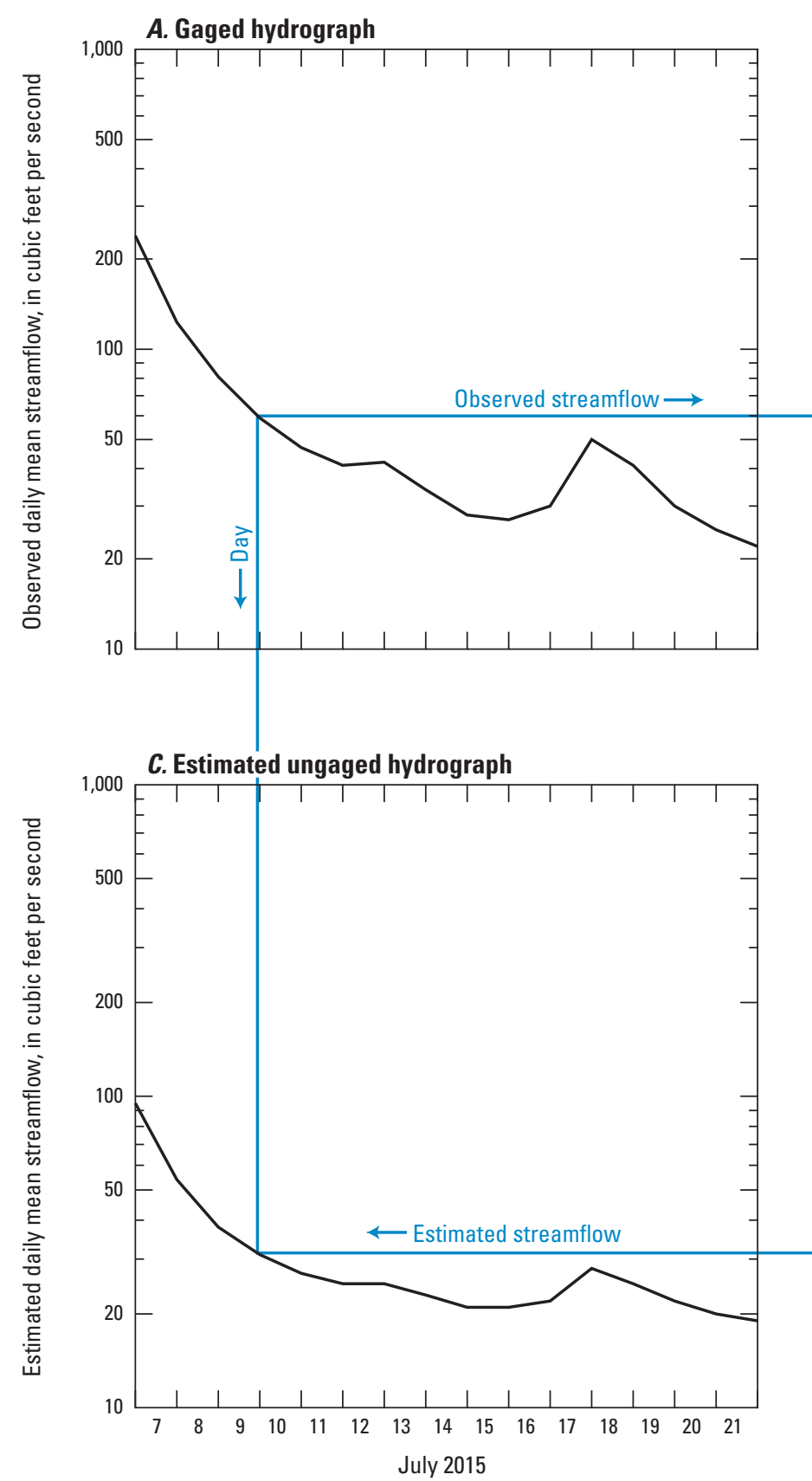

\section{B. Gaged flow-duration curve}

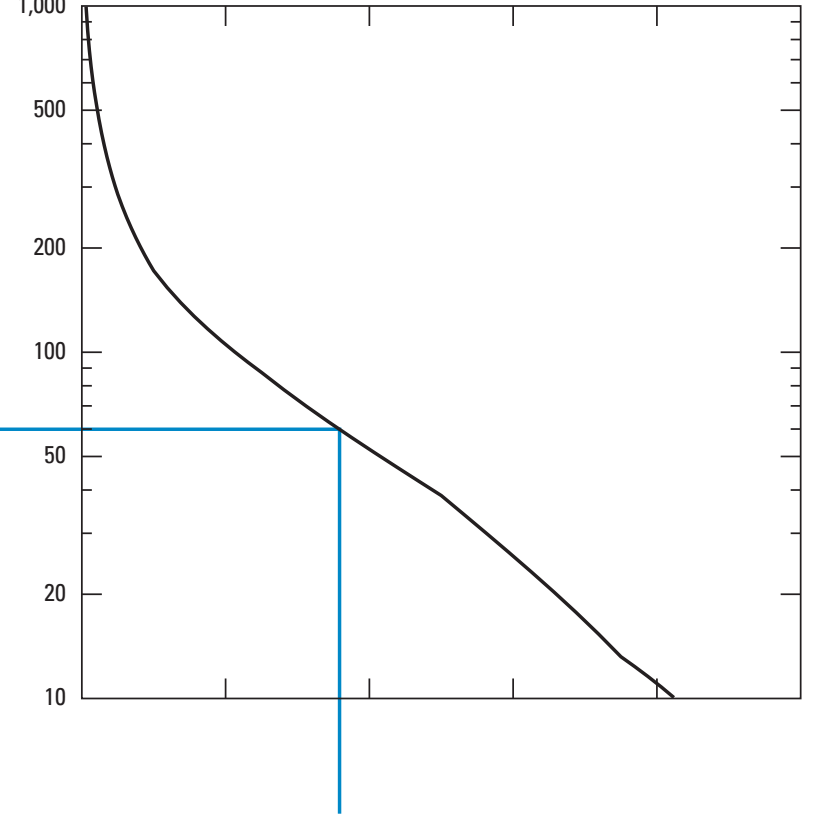

D. Estimated flow-duration curve

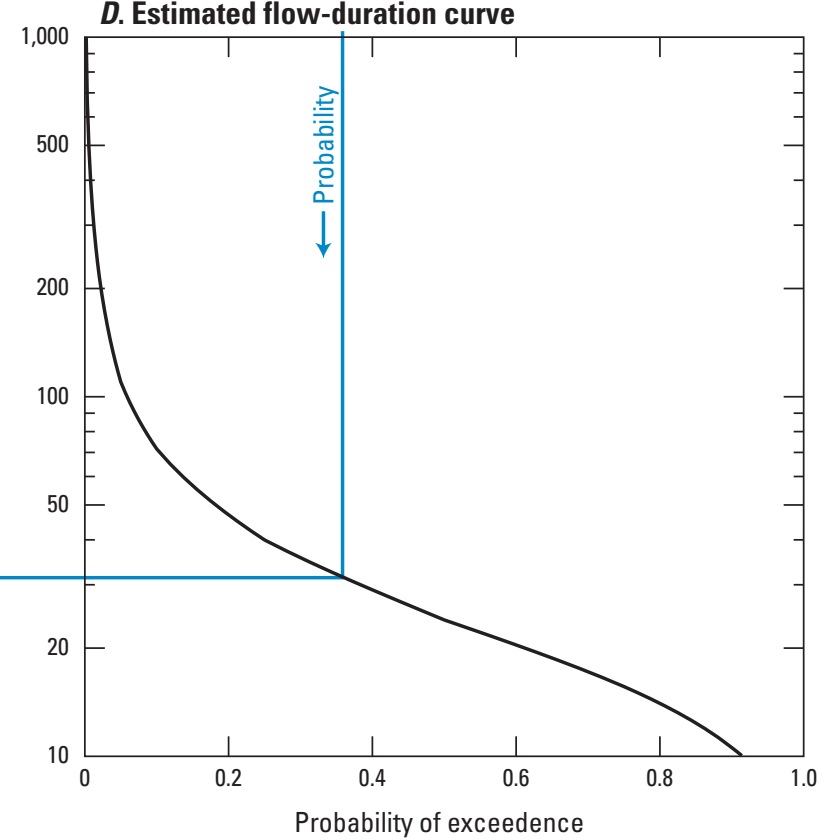

Figure 2. Example of the QPPQ method (Fennessey, 1994) used to estimate daily mean streamflow at ungaged locations for part of the annual hydrograph showing $A$, the gaged hydrograph; $B$, the gaged flow-duration curve; $C$, the estimated flow-duration curve; and $D$, the estimated ungaged hydrograph.

nine pairs of streamgages were randomly selected from the streamgages used in Ziegeweid and others (2015) based on a distance of less than $50 \mathrm{mi}$, drainage-area ratios ranging from 0.25 to 4 , and concurrent record. The selected pairs of streamgages represent a range in distance from 5 to 43 miles and drainage-area ratios from 0.3 to 2.72 (table 2). Only data from the most recent complete water year available from the USGS National Water Information System (U.S. Geological Survey, 2013) common to the pair of streamgages were used in the comparison; a water year is the 12-month period of October 1 through September 30 and is designated by the calendar year in which it ends. For each pair, the index streamgage had the smaller streamgage station number and the target streamgage had the larger streamgage station number. The QPPQ method was applied for the pair after the FDC was estimated at the target streamgage using the regional regression equations. The Spearman's rho values for the selected water year ranged from 0.62 to 0.92 , and the mean Spearman's 
Table 2. Selected pairs of streamgages for assessment of performance of the QPPO method (Fennessey, 1994) for estimating ungaged streamflow in Minnesota.

\begin{tabular}{ccccccc}
\hline $\begin{array}{c}\text { Index station } \\
\text { number }\end{array}$ & $\begin{array}{c}\text { Target station } \\
\text { number }\end{array}$ & $\begin{array}{c}\text { Drainage area ratio } \\
\text { (index/target) }\end{array}$ & $\begin{array}{c}\text { Distance } \\
\text { (miles) }\end{array}$ & Water year & Spearman's rho & $\begin{array}{c}\text { Nash-Sutcliffe } \\
\text { efficiency }\end{array}$ \\
\hline 04014500 & 05124480 & 0.55 & 43 & 1993 & 0.77 & -0.72 \\
04018900 & 04019300 & 2.72 & 19 & 1978 & 0.86 & 0.44 \\
05087500 & 05093000 & 0.92 & 29 & 1956 & 0.81 & -0.20 \\
05093000 & 05107500 & 0.27 & 28 & 1956 & 0.84 & -1.45 \\
05270500 & 05275000 & 1.87 & 32 & 2012 & 0.92 & 0.74 \\
05275000 & 05279000 & 0.48 & 31 & 1979 & 0.62 & 0.60 \\
05372000 & 05374500 & 0.30 & 18 & 1951 & 0.77 & 0.27 \\
05376000 & 05376500 & 1.29 & 5 & 1971 & 0.91 & 0.62 \\
05420680 & 05457700 & 0.32 & 26 & 2012 & 0.78 & 0.42 \\
\hline
\end{tabular}

rho of 0.79 closely approximates the mean Spearman's rho for streamgages in the study area within 50 mi of each other (0.78).

Observed and estimated streamflows for two target streamgages listed in table 2 are compared in figure 3 . The observed and estimated streamflows for streamgage Elk River near Big Lake, Minn. (05275000; fig. 3A) had the largest Spearman's rho between index and target streamgages $(0.92)$. Although the estimated streamflow generally is overestimated for low flows and underestimated for peak flows, the estimated streamflow closely approximates the timing of changes in the measured hydrograph. The observed and estimated streamflows for streamgage South Fork Crow River near Mayer, Minn. (05279000; fig. 3B) had the smallest Spearman's rho between index and target streamgages (0.62). The relation between the estimated and observed low flows (less than 500 cubic feet per second $\left[\mathrm{ft}^{3} / \mathrm{s}\right]$ at streamgage 05279000 and less than $300 \mathrm{ft}^{3} / \mathrm{s}$ at streamgage 05275000 ) was less consistent at streamgage 05279000 (fig. $3 B$ ) than at streamgage 05275000 (fig. $3 A$ ), and the timing and magnitude of the measured spring peak associated with ice-out was misrepresented by the estimated streamflow at streamgage 05279000 . In addition, the estimated streamflow peaks in June and July for streamgage 05279000 were greatly overestimated.

The hydrographs shown in figure 3 illustrate how the magnitudes of observed and estimated streamflows can vary greatly using the methods presented in this report. In figure $3 A$, the observed peak streamflow (in early June) was about 1.8 times larger than the estimated peak streamflow, whereas in figure $3 B$, the estimated peak streamflow in May was about 2.3 times larger than the observed peak streamflow. In addition, for target streamgage Roseau River at Ross, Minn. (05107500), the estimated mean streamflow of $1,400 \mathrm{ft}^{3} / \mathrm{s}$ was about 3.5 times larger than the observed mean streamflow of $406 \mathrm{ft}^{3} / \mathrm{s}$. Such a large difference between the estimated and observed streamflows is unusual for streamgages in region A (fig. 1), where the standard error of the median flow regression is 79 percent (Ziegeweid and others, 2015).
Several methods can be used to evaluate the accuracy of estimated streamflow. The Nash-Sutcliffe efficiency (NSE; Nash and Sutcliffe, 1970) is useful in evaluating estimated streamflow when the goal of the estimation is to closely approximate the actual measured streamflow (Ziegeweid and Magdalene, 2015). Values of the NSE can range from negative infinity to 1.0 , and values close to 1.0 indicate that estimated streamflows closely approximate measured streamflows. The largest NSE value determined for the 9 target streamgages (table 2) was 0.74 . Three of the target streamgages had NSE values less than 0 , indicating the method was worse than the mean of the data at predicting a given streamflow. However, the goal of using the QPPQ method is to reproduce the structure of the hydrograph, not to predict actual streamflow; thus, the results of the NSE analysis are less important for evaluating the QPPQ method that the results of the Spearman's rho analysis.

\section{StreamStats}

StreamStats is a USGS Web-based geographic information system (GIS) tool (http://streamstats.usgs.gov/; Ries and others, 2008) that allows users to obtain streamflow statistics, drainage-basin characteristics, and other information for user-selected locations on streams. Users can select stream locations of interest from an interactive map and can obtain information for these locations. If a user selects the location of a USGS streamgage, the user will get previously published information for the streamgage from a database. If a stream location is selected where no data are available (an ungaged location), a GIS program will estimate information for the location. The GIS program determines the boundary of the drainage basin upstream from the stream location, calculates the basin characteristics of the drainage basin, and solves the appropriate regression equations, based on the physical characteristics of the basin, to estimate streamflow statistics for that location. The results are presented in a table and a 




Figure 3. Observed and estimated streamflows for two target streamgages. $A$, streamgage 05275000 . $B$, streamgage 05279000 . 
map showing the basin-boundary outline. These estimates are applicable for stream locations not substantially affected by regulation, diversions, or urbanization. The regression equations developed by Ziegeweid and others (2015) to estimate FDC and LFF statistics in the study area have been incorporated into StreamStats. StreamStats can estimate FDCs at ungaged locations on unaltered streams; the estimated FDCs are then used in the QPPQ method to estimate streamflow.

\section{Limitations of the Methods}

The methods presented in this study have several limitations. The regional regression equations developed by Ziegeweid and others (2015) apply only to stream locations in Minnesota where streamflow is not substantially affected by regulation, diversions, or urbanization. Furthermore, the applicability and accuracy of the regional equations depend on whether the basin characteristics calculated for an ungaged stream location are within the range of the characteristic values used to develop the regression equations. In addition, selection of an index streamgage is based primarily on proximity of the streamgage to the ungaged location. Although the closest streamgage should provide good estimates of streamflow statistics, other factors need to be considered in order to select the index streamgage that provides the most accurate estimates of streamflow statistics. For example, if the streamflow upstream from the nearest streamgage is affected substantially by an upstream lake or wetland, and the ungaged location is not affected substantially by a lake or wetland, then the user might consider selecting a different index streamgage that is unaffected by lakes or wetlands upstream from the streamgage.

\section{Summary}

Effective and responsible management of water resources relies on a thorough understanding of the quantity and quality of available water; however, streamgages cannot be installed at every location where streamflow information is needed. Therefore, methods for estimating streamflow at ungaged locations need to be developed. This report presents the results of a statewide study to develop methods to estimate the structure of historical daily streamflow at ungaged stream locations in Minnesota. Historical daily mean streamflow at ungaged locations in Minnesota can be estimated by transferring streamflow data at streamgages to the ungaged location using the QPPQ method. The QPPQ method uses flow-duration curves at index streamgages and ungaged locations and relies on the assumption that exceedance probabilities are equivalent between an index streamgage and an ungaged location. Flow-duration curves at ungaged locations can be estimated using recently developed regression equations that have been incorporated into StreamStats (http://streamstats.usgs.gov/), which is a
USGS Web-based interactive mapping tool that can be used to obtain streamflow statistics, drainage-basin characteristics, and other information for user-selected locations on streams.

Nine pairs of streamgages and Spearman's rho were used to evaluate the ability of the QPPQ method to predict measured (observed) hydrographs. Spearman's rho for the nine target streamgages ranged from 0.62 to 0.92 , with a mean $(0.79)$ that closely approximates the mean Spearman's rho for streamgages in the study area within 50 miles of each other (0.78).

\section{Acknowledgments}

Scott Bennett, a contract employee at the U.S. Geological Survey (USGS) Minnesota Water Science Center, created the study area map and compiled the basin characteristics. Erik Smith of the USGS Minnesota Water Science Center and David Bender of the USGS South Dakota Water Science Center improved the report by their careful reviews.

\section{References Cited}

Archfield, S.A., Vogel, R.M., Steeves, P.A., Brandt, S.L., Weiskel, P.K., and Garabedian, S.P., 2010, The Massachusetts Sustainable-Yield Estimator-A decision-support tool to assess water availability at ungaged stream locations in Massachusetts: U.S. Geological Survey Scientific Investigations Report 2009-5227, 41 p. [Also available at http:// pubs.er.usgs.gov/publication/sir20095227.]

Farmer, W.H., Archfield, S.A., Over, T.M., Hay, L.E., LaFontaine, J.H., and Kiang, J.E., 2014, A comparison of methods to predict historical daily streamflow time series in the southeastern United States: U.S. Geological Survey Scientific Investigations Report 2014-5231, 34 p. [Also available at http://dx.doi.org/10.3133/sir20145231.]

Fennessey, N.M., 1994, A hydro-climatological model of daily streamflow for the northeast United States: Medford, Massachusetts, Tufts University, Ph.D. dissertation, [variously paged].

Gazoorian, C.L., 2015, Estimation of unaltered daily means streamflow at ungaged streams of New York, excluding Long Island, water years 1961-2010: U.S. Geological Survey Scientific Investigations Report 2014-5220, 29 p. [Also available at http://dx.doi.org/10.3133/sir20145220.]

Helsel, D.R., and Hirsch, R.M., 2002, Statistical methods in water resources: U.S. Geological Survey Techniques of Water-Resources Investigations, book 4, chap. A3, 524 p. [Also available at http://pubs.usgs.gov/twri/twri4a3/.] 
Hirsch, R.M., 1982, A comparison of four streamflow record extension techniques: Water Resources Research, v. 18, no. 4, p. 1081-1088. [Also available at http://dx.doi. org/10.1029/WR018i004p01081.]

Hughes, D.A., and Smakhtin, V.U., 1996, Daily flow time series patching or extension-A spatial interpolation approach based on flow duration curves: Hydrological Sciences Journal, v. 41, no. 6, p. 851-871. [Also available at http://dx.doi.org/10.1080/02626669609491555.]

Jacques, J.E., and Lorenz, D.L., 1988, Techniques for estimating the magnitude and frequency of floods in Minnesota: U.S. Geological Survey Water-Resources Investigations Report 87-4170, 48 p. [Also available at http://pubs.er.usgs. gov/publication/wri874170 ]

Linhart, S.M., Nania, J.F., Christiansen, D.E., Hutchinson, K.J., Sanders, C.L., Jr., and Archfield, S.A., 2013, Comparison between two statistically based methods, and two physically based models developed to compute daily mean streamflow at ungaged locations in the Cedar River Basin, Iowa: U.S. Geological Survey Scientific Investigations Report 2013-5111, 7 p. [Also available at http://pubs.usgs. gov/sir/2013/5111/.]

Lorenz, D.L., Carlson, G.H., and Sanocki, C.A., 1997, Techniques for estimating peak flow on small streams in Minnesota: U.S. Geological Survey Water-Resources Investigations Report 97-4249, 42 p. [Also available at http://pubs. er.usgs.gov/publication/wri974249.]

Lorenz, D.L., Sanocki, C.A., and Kocian, M.J., 2010, Techniques for estimating the magnitude and frequency of peak flows on small streams in Minnesota based on data through water year 2005: U.S. Geological Survey Scientific Investigations Report 2009-5250, 54 p. [Also available at http:// pubs.usgs.gov/sir/2009/5250/.]

Mahamoud, Y.M., 2008, Prediction of daily flow duration curves and streamflow for ungauged catchments using regional flow duration curves: Hydrological Sciences Journal, v. 53, no. 4, p. 706-724. [Also available at http://dx.doi. org/10.1623/hysj.53.4.706.]

Nash, J.E., and Sutcliffe, J.V., 1970, River flow forecasting through conceptual models part I-A discussion of principles: Journal of Hydrology, v. 10, no. 3, p. 282-290. [Also available at http://dx.doi.org/10.1016/0022-1694(70)902556.]

Ries, K.G., III, Guthrie, J.D., Rhea, A.H., Steeves, P.A., and Stewart, D.W., 2008, StreamStats-A water resources Web application: U.S. Geological Survey Fact Sheet 2008-3067, 6 p. [Also available at http://pubs.usgs.gov/fs/2008/3067/.]

Searcy, J.K., 1959, Flow-duration curves: U.S. Geological Survey Water-Supply Paper 1542-A, 33 p. [Also available at http://pubs.er.usgs.gov/publication/wsp1542A/.]
Shu, C., and Ouarda, T.B.M.J., 2012, Improved methods for daily streamflow estimates at ungauged sites: Water Resources Research, v. 48, no. 2, W02523. [Also available at http://dx.doi.org/10.1029/2011WR011501.]

Smakhtin, V.U., 1999, Generation of natural daily flow time series in regulated rivers using a non-linear spatial interpolation technique: Regulated Rivers-Research and Management, v. 15, no. 4, p. 311-323. [Also available at http://dx.doi.org/10.1002/(SICI)10991646(199907/08)15:4<311::AID-RRR544>3.0.CO;2-W.]

Smakhtin, V.U., and Masse, B., 2000, Continuous daily hydrograph simulation using duration curves of a precipitation index: Hydrological Processes, v. 14, no. 6, p. 1083-1100. [Also available at http://dx.doi.org/10.1002/(SICI)10991085(20000430)14:6<1083::AID-HYP998>3.0.CO;2-2.]

Stuckey, M.H., Koerkle, E.H., and Ulrich, J.E., 2012, Estimation of baseline daily mean streamflows for ungaged locations on Pennsylvania streams, water years 1960-2008: U.S. Geological Survey Scientific Investigations Report 2012-5142, 61 p. [Also available at http://pubs.usgs.gov/ $\operatorname{sir} / 2012 / 5142$.]

U.S. Geological Survey, 2013, National Water Information System (NWISWeb): U.S. Geological Survey database, accessed 05/03/2013, at http://waterdata.usgs.gov/nwis/sw.

U.S. Geological Survey, 2015, StreamStats: accessed November 10, 2015, at http://streamstats.usgs.gov/.

Vogel, R.M., and Stedinger, J.R., 1985, Minimum variance streamflow record augmentation procedures: Water Resources Research, v. 21, no. 5, p. 715-723. [Also available at http://dx.doi.org/10.1029/WR021i005p00715.]

Winter, T.C., 2001, The concept of hydrologic landscapes: Journal of the American Water Resources Association, v. 37, no. 2, p. 335-349. [Also available at http://dx.doi. org/10.1111/j.1752-1688.2001.tb00973.x.]

Wolock, D.M., Winter, T.C., and McMahon, G., 2004, Delineation and evaluation of hydrologic-landscape regions in the United States using geographic information system tools and multivariate statistical analyses: Environmental Management, v. 34, supplement 1, p. S71-S88. [Also available at http://dx.doi.org/10.1007/s00267-003-5077-9.]

Ziegeweid, J.R., Lorenz, D.L., Sanocki, C.A., and Czuba, C.R., 2015, Methods for estimating flow-duration curve and low-flow frequency statistics for ungaged locations on small streams in Minnesota: U.S. Geological Survey Scientific Investigations Report 2015-5170, 29 p. [Also available at http://dx.doi.org/10.3133/sir20155170.] 
Ziegeweid, J.R., and Magdalene, Suzanne, 2015, Development of regression equations to revise estimates of historical streamflows for the St. Croix River at Stillwater, Minnesota (water years 1910-2011), and Prescott, Wisconsin (water years 1910-2007): U.S. Geological Survey Scientific Investigations Report 2014-5239, 23 p. [Also available at http:// dx.doi.org/10.3133/sir20145239.] 
Table 1 


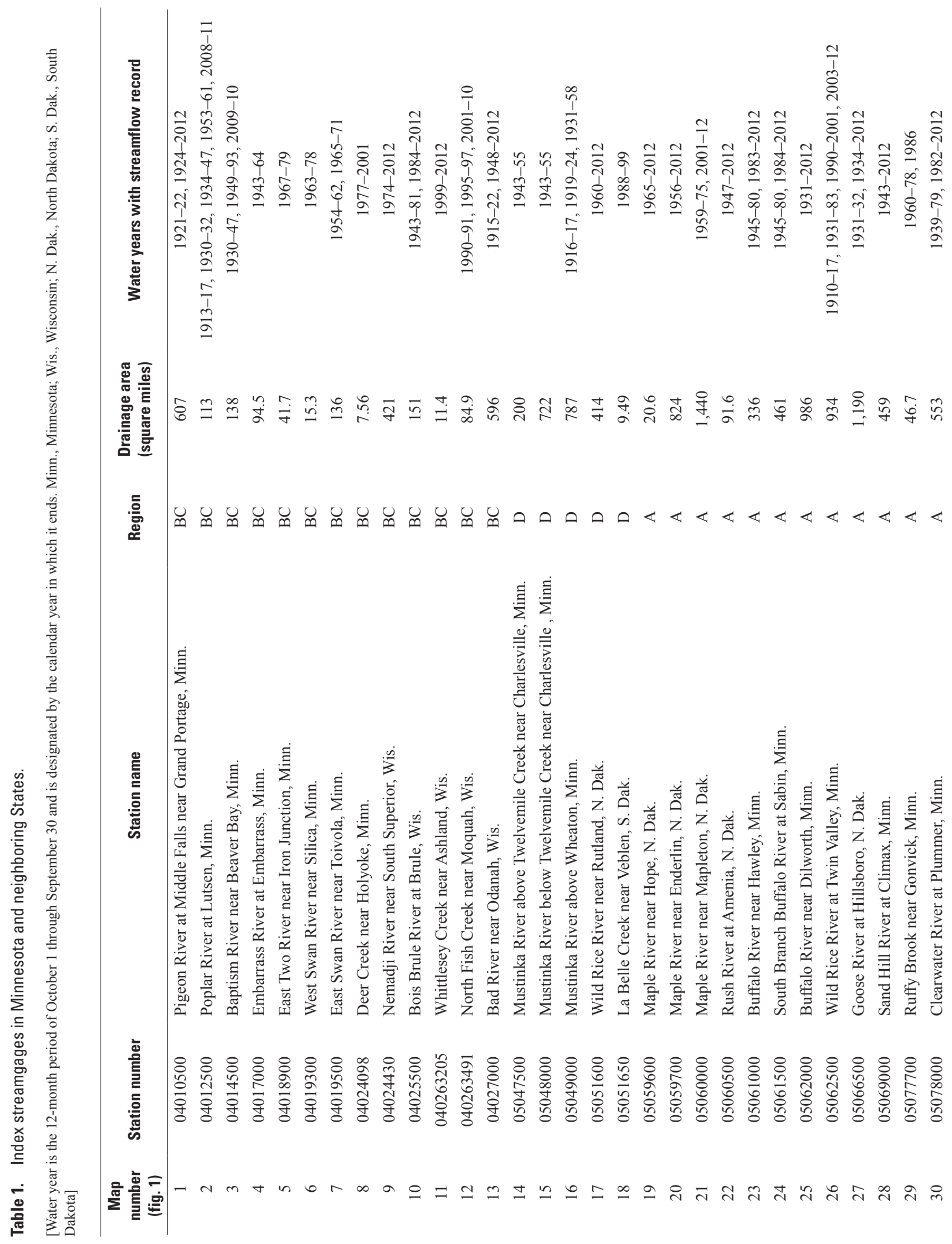


Table 113

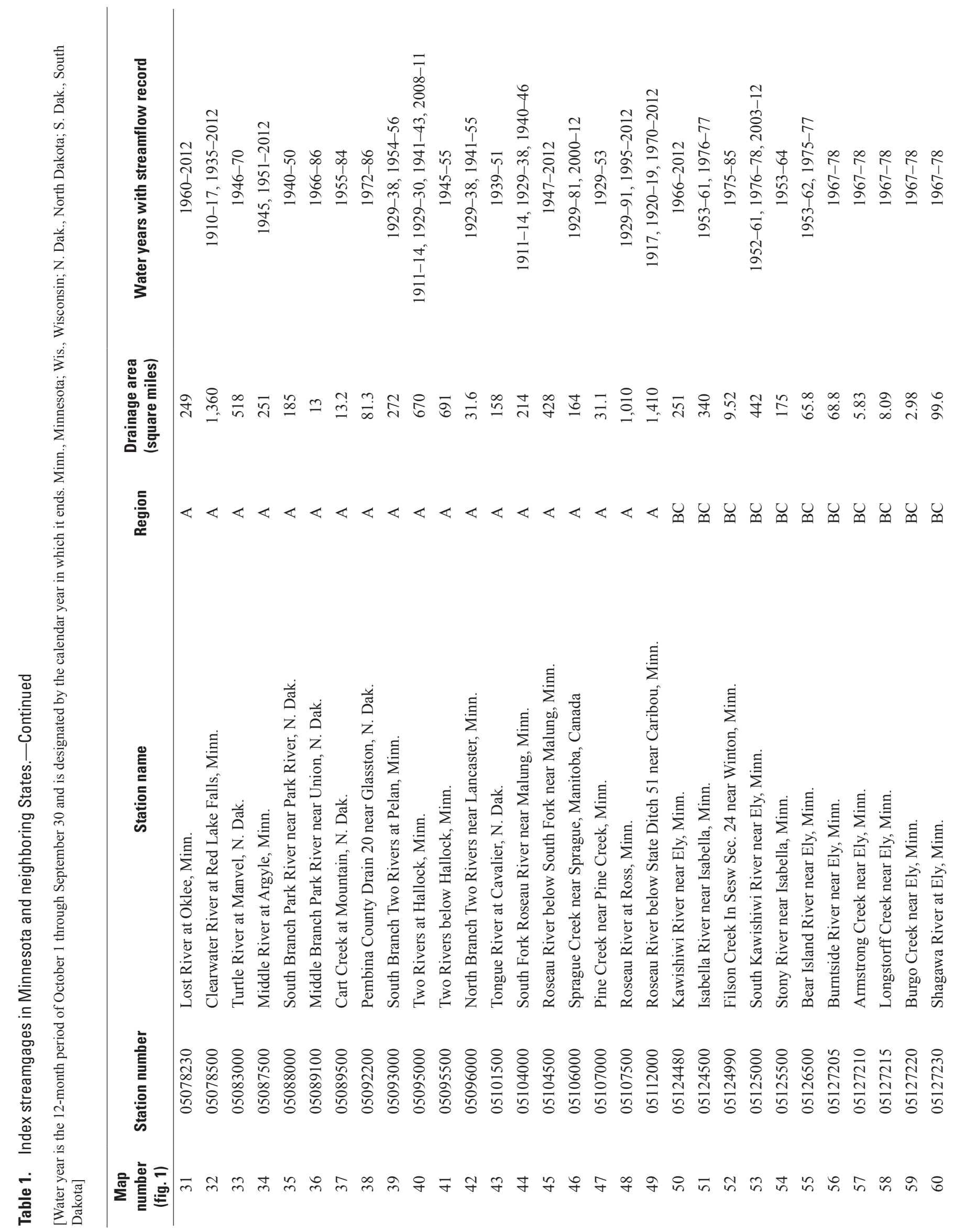




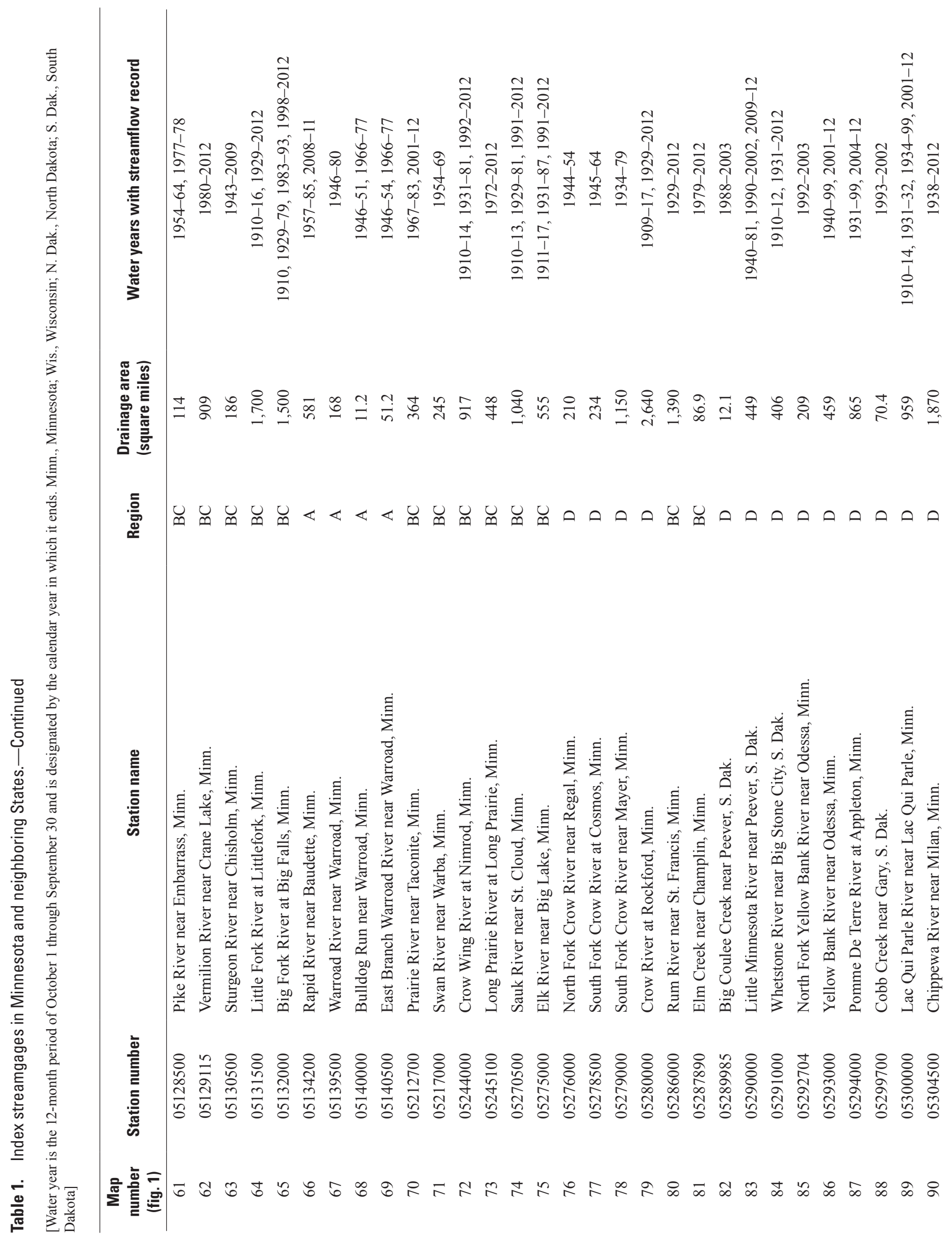


Table $1 \quad 15$

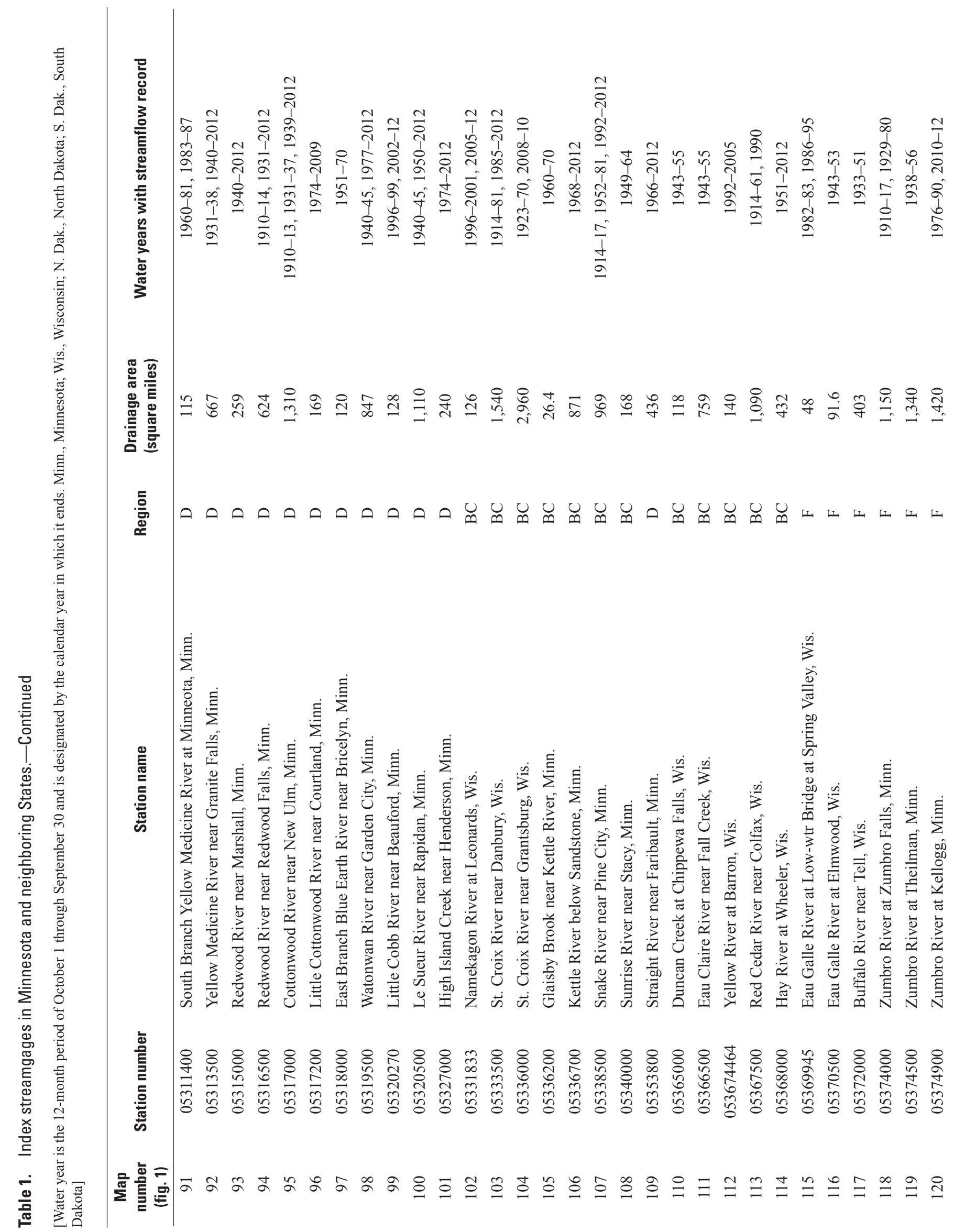




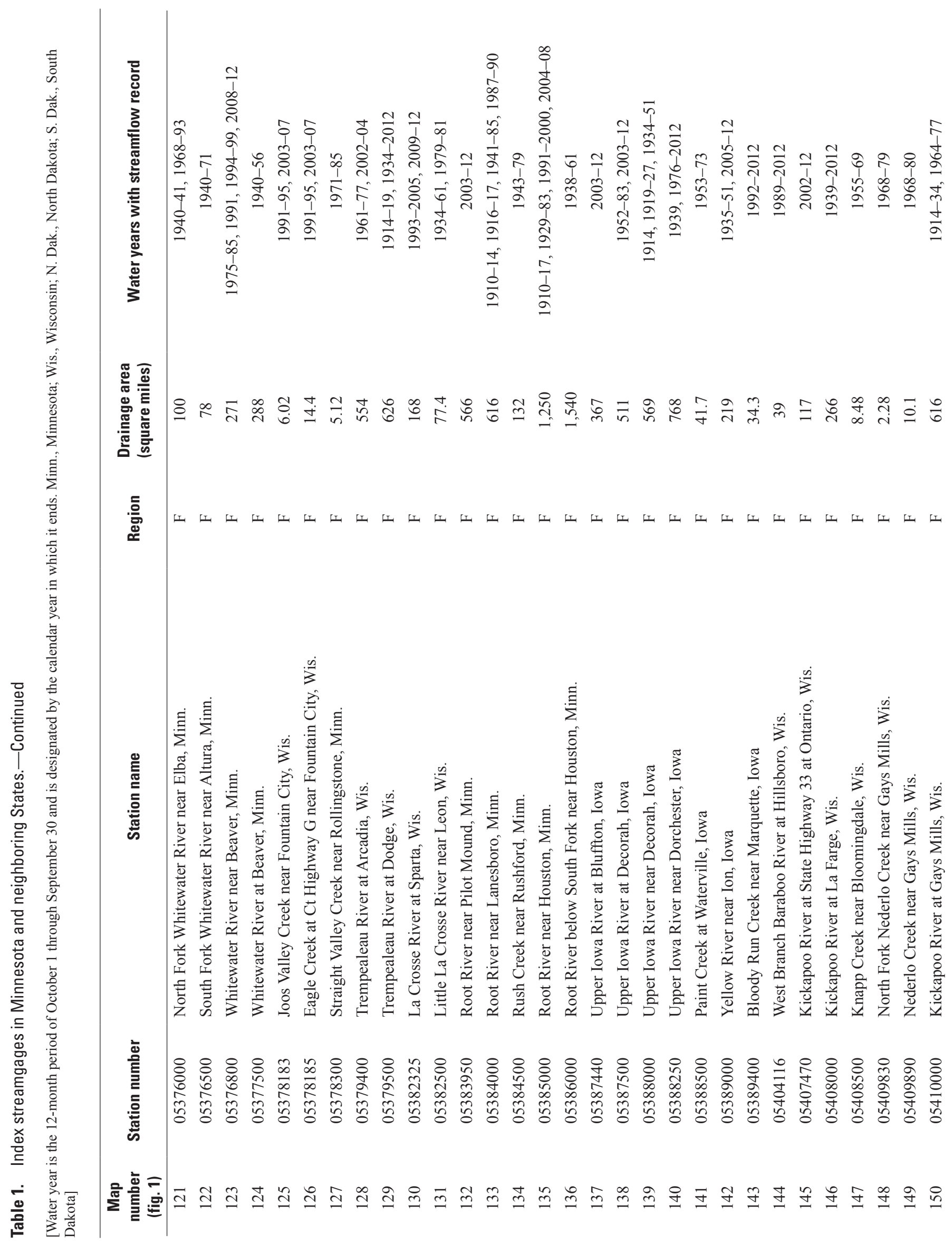


Table $1 \quad 17$

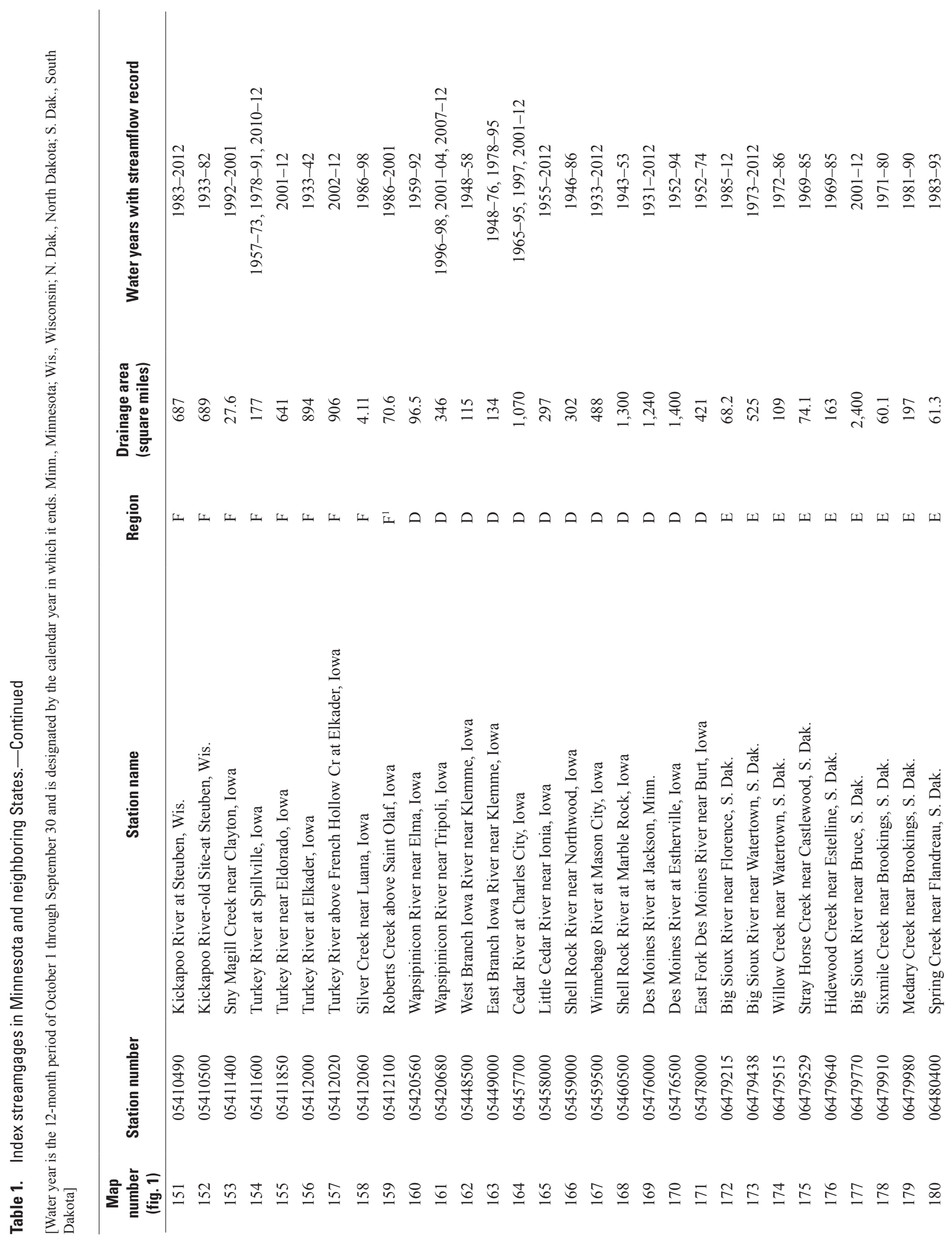




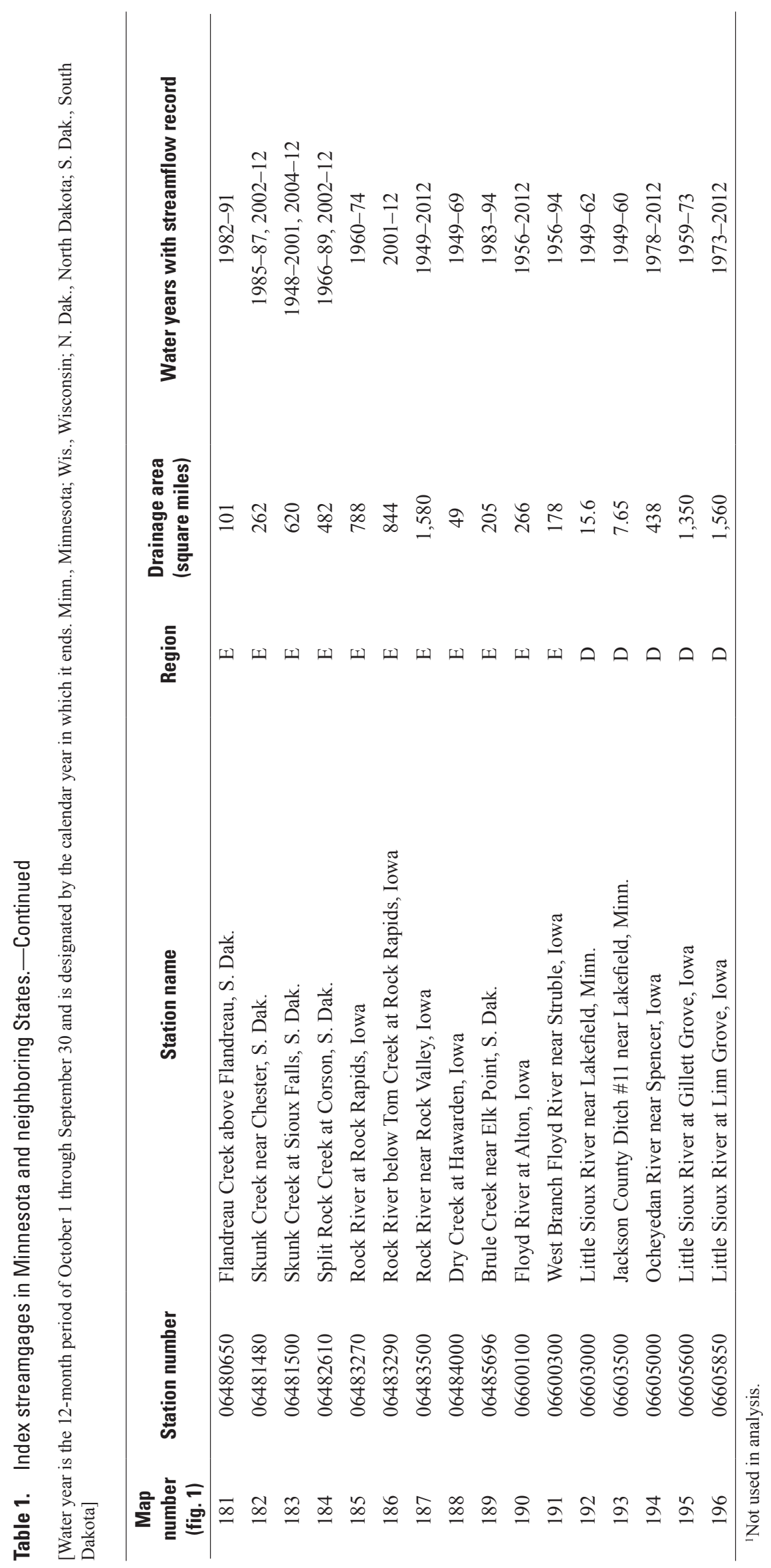


Publishing support provided by:

Rolla Publishing Service Center

For more information concerning this publication, contact: Director, USGS Minnesota Water Science Center 2280 Woodale Drive

Mounds View, Minnesota 55112

(763) 783-3100

Or visit the Minnesota Water Science Center Web site at: http://mn.water.usgs.gov/ 




\section{$\frac{\mathbb{3}}{3}$}

